\begin{tabular}{|l|l|}
\hline JITAS & JAGROS Journal of Agrotechnonogy and Science \\
& Jurnal Agroteknologi dan sains \\
Fakultas Pertanian, Universitas Garut \\
PISSN : 2775-0485, E ISSN : 2548-7752
\end{tabular}

\title{
Pengaruh berbagai konsentrasi zat pengatur tumbuh hydrasil dan dosis pupuk kandang ayam terhadap pertumbuhan dan hasil Tanaman pakchoy(Brassica rapa $\mathbf{L}$.)
}

\author{
Rizki Adi Muharam¹, Jenal Mutakin², Siti Syarah Maesyaroh ${ }^{3}$ \\ Program Studi Agroteknologi, Fakultas Pertanian, Universitas Garut \\ Jalan Raya Samarang Nomor 52A, Garut \\ Email : fernandorizky9@gmail.com
}

\begin{abstract}
Abstrak
Pakchoy (Brassica rappa L.) adalah tanaman jenis sayuran yang termasuk keluarga Brassicaceae. Penelitian bertujuan untuk mengetahui kombinasi konsentrasi ZPT hydrasil dan dosis pupuk kandang ayam yang memberikan pengaruh lebih tanaman pakchoy. Penelitian dilaksanakan di Kampung Cipangsor Kaler, Desa Sukajaya, Kecamatan Tarogong Kidul, Kabupaten Garut berketinggian tempat 761 meter di atas permukaan laut dengan tekstur tanah liat dan tipe curah hujan C. Penelitian dilaksanakan pada bulan Februari sampai April 2021. Metode yang digunakan dalam penelitian adalah eksiperimental dengan menggunakan rancangan acak kelompok (RAK) pola faktorial 4 x 4 diulang 2 kali. Faktor pertama konsentrasi ZPT terdiri dari 4 taraf yaitu $\mathrm{z}_{0}=0,0 \mathrm{ml} /$ liter air, $\mathrm{z}_{1}=1.0 \mathrm{ml} / \mathrm{liter}$ air, $\mathrm{z}_{2}$ $=1.5 \mathrm{ml} /$ liter air dan $\mathrm{z}_{3}=2.0 \mathrm{ml} /$ liter air. Faktor kedua adalah dosis pupuk kandang ayam terdiri dari 4 taraf yaitu $\mathrm{k}_{0}=0,0$ ton $/ \mathrm{ha}, \mathrm{k}_{1}=7.5$ ton $/ \mathrm{ha}, \mathrm{k}_{2}=10,0$ ton $/ \mathrm{ha}$ dan $\mathrm{k}_{3}=12.5$ ton $/ \mathrm{ha}$. Hasil penelitian menunjukkan terjadi interaksi antara konsentrasi ZPT dan dosis pupuk kandang ayam terhadap bobot segar tanaman dan hasil segar tanaman per plot. Kombinasi perlakuan konsentrasi ZPT 1,5 ml/liter air dengan dosis pupuk kandang ayam 12,5 ton/ha berpengaruh terbaik terhadap pertumbuhan dan hasil pakchoy.

Kata kunci: Dosis, Konsentrasi, Pakchoy, Pupuk kandang ayam, ZPT Hydrasil.
\end{abstract}

\begin{abstract}
Pakchoy (Brassica rappa L.) is a type of vegetable plant that belongs to the Brassicaceae. The aim of the study was to determine the combination of ZPT Hydrasil concentration and dose of chicken manure which had more effect on pakchoy plants. The research was carried out in Cipangsor Kaler, Sukajaya Village, Tarogong Kidul District, Garut Regency at an altitude of 761 meter above sea level with clay texture and rainfall type $C$. The study was carried out from February to April 2021. The method used in this study was experimental by using a randomized block design (RAK) factorial pattern $4 \times 4$ repeated
\end{abstract}


2 times. The first factor consisted 4 levels of ZPT concentration $z_{0}=0.0 \mathrm{ml} /$ liter of water, $z_{1}=1.0$ $\mathrm{ml} /$ liter of water, $z_{2}=1.5 \mathrm{ml} /$ liter of water and $z_{3}=2.0 \mathrm{ml} / \mathrm{liter}$ of water. The second factor is the dose of chicken manure consisting of 4 levels $k_{0}=0.0$ tons $/ \mathrm{ha}, k_{1}=7.5$ tons $/ \mathrm{ha}, k_{2}=10$ tons $/ \mathrm{ha}$ and $k_{3}=12.5$ tons/ha.The results showed that there was an interaction between ZPT concentration and dose of chicken manure on plant fresh weight and plant fresh yield a plot. The combination of treatment with ZPT concentration of $1.5 \mathrm{ml} /$ liter of water with a dose of chicken manure 12.5 tons/Ha had the best effect on the growth and yield of pakchoy.

Keyword: Consentration, Chicken manure, Dose, Pakchoy, ZPT hydrasil.

\section{Pendahuluan}

Pakchoy (Brassica rapa L.) merupakan salah satu tanaman holtikultura yang cukup popular dan diminati masyarakat karena mengandung banyak manfaat dari mulai protein, lemak dan vitamin yang terdapat dalam tanaman pakchoy tersebut. Tanaman pakchoy juga memiliki nilai ekonomis yang tinggi (Haryanto, 2007).

Berdasarkan data Badan Pusat Statistik (2018), produksi tanaman pakchoy di Indonesia dari tahun 2015 sampai 2017 adalah tahun 2015 luas panen 58.652 ha jumlah produksi panen 600.200 ton dan produktivitas per tahun 10.23 ton, tahun 2016 luas panen 60.600 ha jumlah produksi panen 601.204 ton dan produktivitas per tahun 9.92 ton dan tahun 2017 luas panen 61.133 ha jumlah produksi panen 627.598 ton dan produktivitas per tahun 10.27 ton. Data tersebut menunjukkan bahwa pada tahun 2016 sempat mengalami penurunan dan tahun selanjutnya mengalami peningkatan hasil produksi tanaman pakchoy.

Upaya perbaikan yang dapat dilakukan diantaranya dengan cara pemberian pupuk yang berimbang antara pupuk organik dan pupuk sintetis atau kimia sesuai kebutuhannya. Pemberian pupuk melalui tanah untuk kebutuhan tanaman pakchoy tidaklah menjamin untuk tumbuh dan berkembang dengan cepat, maka perlu ditambah dengan pemberian ZPT. Pupuk kandang ayam berfungsi untuk memeperbaiki sifat fisik, kimia dan biologi tanah pupuk kandang ayam juga mempunyai kandungan N, P dan K yang lebih tinggi bila dibandingkan pupuk kandang lainnya (Sutejo, 2005) dan ZPT merupakan senyawa yang diberikan ke tanaman sebagai suplemen tambahan untuk meningkatkan proses pembelahan sel agar lebih aktif lagi (Heddy, 1996).

\section{Metodologi}

Penelitian dilaksanakan di Kampung Cipangsor Kaler, Desa Sukajaya, Kecamatan Tarogong Kidul, Kabupaten Garut dengan ketinggian tempat 761 meter di atas permukaan laut dengan tekstur tanah liat. Tipe curah hujan berdasarkan kriteria Schmidt dan Ferguson (1951) adalah tipe curah hujan C. Penelitian dilaksanakan pada bulan Februari sampai April 2021.

Bahan yang digunakan yaitu benih pakchoy emone 26, pupuk kandang ayam dan ZPT hydrasil. Alat yang digunakan pada penelitian adalah kertas label, tali raffia, plastik, mulsa, ajir, timbangan digital, alat pengukur penggaris $50 \mathrm{~cm}$, cangkul, ember, alat penyemprot, alat-alat tulis dan tugar.

Teknik yang dipakai pada peneltian ini ialah metode eksperemental dengan RAK (Rancangan Acak Kelompok) dengan konsep faktorial 4x4 dan dua kali ulangan. Tingkat perbedaan masing-masing perlakuan, maka dilakukan uji $\mathrm{F}$ dengan kaidah pengambilan 
keputusan. Jika ternyata $F_{\text {hit }}$ lebih besar dari $F_{0.05}$, maka dilakukan uji lanjutan dengan menggunakan Uji Jarak Berganda Duncan (Warsa dan Akhyar, 1982).

\section{Hasil dan Pembahasaan}

\section{Tinggi Tanaman}

Analisis hasil pengamatan tinggi tanaman menunjukkan tidak terjadi interaksi antara berbagai konsentrasi zat pengatur tumbuh hydrasil dan dosis pupuk kandang ayam terhadap tinggi tanaman.

Tabel 1. Pengaruh Berbagai Konsentrasi Zat Pengatur Tumbuh Hydrasil dan Dosis Pupuk Kandang Ayam terhadap Tinggi Tanaman.

\begin{tabular}{llllllll}
\hline \multirow{2}{*}{ Perlakuan } & \multicolumn{7}{c}{ Rata-rata tinggi tanaman (cm) } \\
\cline { 2 - 7 } & 15 HST & 22 HST & 29 HST & \\
\hline Konsentrasi Zat Pengatur Tumbuh & & & & & & \\
$\mathrm{z}_{0}=0,0 \mathrm{ml} /$ liter air & 10,38 & $\mathrm{a}$ & 16,15 & $\mathrm{a}$ & 22,56 & $\mathrm{a}$ \\
$\mathrm{z}_{1}=1.0 \mathrm{ml} /$ liter air & 12,47 & $\mathrm{~b}$ & 17,38 & $\mathrm{~b}$ & 23,02 & $\mathrm{a}$ \\
$\mathrm{z}_{2}=1.5 \mathrm{ml} /$ liter air & 14,28 & $\mathrm{c}$ & 18,03 & $\mathrm{~b}$ & 26,97 & $\mathrm{c}$ \\
$\mathrm{z}_{3}=2.0 \mathrm{ml} /$ liter air & 13,86 & $\mathrm{c}$ & 17,47 & $\mathrm{~b}$ & 25,50 & $\mathrm{~b}$ \\
\hline Dosis Pupuk Kandang Ayam & & & & & & \\
$\mathrm{k}_{0}=0,0$ ton/ha & 12,11 & $\mathrm{a}$ & 16,26 & $\mathrm{a}$ & 23,16 & $\mathrm{a}$ \\
$\mathrm{k}_{1}=7.5$ ton/ha & 12,69 & $\mathrm{~b}$ & 17,07 & $\mathrm{~b}$ & 24,30 & $\mathrm{~b}$ \\
$\mathrm{k}_{2}=10,0$ ton/ha & 12,71 & $\mathrm{~b}$ & 17,60 & $\mathrm{bc}$ & 24,78 & $\mathrm{~b}$ \\
$\mathrm{k}_{3}=12.5$ ton/ha & 13,49 & $\mathrm{c}$ & 18,11 & $\mathrm{c}$ & 25,81 & $\mathrm{c}$ \\
\hline
\end{tabular}

Keterangan: Angka rata-rata yang diikuti huruf yang sama pada setiap kolom, tidak berbeda nyata berdasarkan Uji Jarak Berganda Duncan pada taraf nyata 5\%.

Pemberian konsentrasi zat pengatur tumbuh dengan konsentrasi 1,5 ml/liter air merupakan konsentrasi yang tepat dalam memacu pertumbuhan tinggi tanaman, karena zat pengatur tumbuh mempunyai sifat merangsang, menghambat dan mengubah proses fisiologis pada tanaman. Apabila konsentrasi yang digunakan terlalu tinggi menyebabkan kematian bagi tanaman, sedangkan konsentrasi pemberian yang terlalu rendah menyebabkan menurunnya efek zat pengatur tumbuh tersebut. Menurut Darnell dkk. (1986) yang dikutip Purwitasari dkk. (2012) auksin merupakan salah satu hormon tanaman yang dapat mendukung proses fisiologi seperti pertumbuhan, pembelahan dan diferensiasi sel serta sintesa protein.

Meningkatnya rata-rata tinggi tanaman pada perlakuan pemberian kotoran ayam yang semakin tinggi yaitu 12,5 ton/ha karena pupuk kandang ayam pada dosis tersebut mampu mempengaruhi kesuburan tanah. Menurut Novizan (2005) penambahan bahan organik membuat tanah bersifat lebih gembur, sehingga aerasinya lebih baik dan tidak mudah mengalami pemadatan dibandingkan dengan tanah yang mengandung bahan organik rendah. Pupuk kandang ayam dalam tanah bermanfaat mempercepat aktivitas mikro organisme, sehingga 
meningkatkan kecepatan dekomposisi bahan organik dan mempercepat pelepasan hara. Pemberian pupuk organik dengan dosis yang tinggi akan memacu pembiakan mikroba, memfiksasi beberapa unsur hara atau imobilitas N yang bersifat sementara (Sudiarto dan Gusmaini, 2006).

\section{Jumlah Daun}

Analisis hasil pengamatan jumlah daun menunjukkan tidak terjadi interaksi amtara berbagai konsentrasi zat pengaturtumbuhhydrasil dan dosis pupuk kandang ayam terhadap jumlah daun. Perlakuan konsentrasi zat pengatur tumbuh yang diteliti menunjukkan bahwa peningkatan jumlah daun pakchoy tertinggi diperoleh pada konsentrasi $1,5 \mathrm{ml} / \mathrm{l}$ air. Hal ini diduga pada konsentrasi tersebut bahan aktif 2,4-D dalam keadaan optimum sehingga dapat merangsang lebih giat kerja auksin. pemberian zat pengatur tumbuh pada jumlah yang optimum akan merangsang aktivitas auksin dan pembelahan sel pada jaringan meristimatik sehingga berpengaruh terhadap pertumbuhan. Proses utama yang dirangsang auksin terhadap pertumbuhan vegetatif adalah pembelahan sel, pembesaran sel dan deferensiasi sel yang meliputi pembentukan daun (Heddy, 1996).

Hasil penelitian menunjukkan bahwa meningkatnya pemberian dosis pupuk kandang ayam berpengaruh meningkatkan rata-rata jumlah daun. Hal ini disebabkan pupuk kandang dapat meningkatkan pembentukan agregat dan struktur tanah dengan meningkatnya populasi mikroorganisme tanah sehingga berpengaruh terhadap penyerapan unsur hara oleh tanaman. Dikemukakan Gardner dkk. (1991) bahwa unsur hara N meningkatkan jumlah klorofil pada daun dan menyebabkan proses fotosintesis berlangsung dengan baik karena kandungan klorofil dapat menangkap energi cahaya matahari dan menghasilkan karbohidrat lebih banyak yang berguna untuk perkembangan lebar daun.

Tabel 2. Pengaruh Berbagai Konsentrasi Zat Pengatur Tumbuh Hydrasil dan Dosis Pupuk Kandang Ayam terhadap Jumlah Daun.

\begin{tabular}{|c|c|c|c|c|c|c|}
\hline \multirow{2}{*}{ Perlakuan } & \multicolumn{6}{|c|}{ Rata-rata jumlah daun (helai) } \\
\hline & \multicolumn{2}{|c|}{$15 \mathrm{HST}$} & \multicolumn{2}{|c|}{$22 \mathrm{HST}$} & \multicolumn{2}{|c|}{$29 \mathrm{HST}$} \\
\hline \multicolumn{7}{|c|}{ Konsentrasi Zat Pengatur Tumbuh } \\
\hline $\mathrm{z}_{0}=0,0 \mathrm{ml} /$ liter air & 4,59 & $\mathrm{a}$ & 5,66 & $\mathrm{a}$ & 7,81 & $\mathrm{a}$ \\
\hline $\mathrm{z}_{1}=1.0 \mathrm{ml} /$ liter air & 4,66 & $a b$ & 5,75 & $\mathrm{a}$ & 8,13 & $a b$ \\
\hline $\mathrm{z}_{2}=1.5 \mathrm{ml} /$ liter air & 4,81 & $\mathrm{~b}$ & 6,78 & $\mathrm{~b}$ & 9,00 & $\mathrm{c}$ \\
\hline $\mathrm{z}_{3}=2.0 \mathrm{ml} /$ liter air & 4,78 & $\mathrm{ab}$ & 6,75 & $\mathrm{~b}$ & 8,53 & $\mathrm{bc}$ \\
\hline \multicolumn{7}{|c|}{ Dosis Pupuk Kandang Ayam } \\
\hline $\mathrm{k}_{0}=0,0$ ton $/ \mathrm{ha}$ & 4,56 & $\mathrm{a}$ & 5,78 & $\mathrm{a}$ & 7,69 & $\mathrm{a}$ \\
\hline $\mathrm{k}_{1}=7.5 \mathrm{ton} / \mathrm{ha}$ & 4,63 & $\mathrm{a}$ & 6,03 & $a b$ & 8,28 & $\mathrm{~b}$ \\
\hline $\mathrm{k}_{2}=10,0$ ton $/ \mathrm{ha}$ & 4,72 & $\mathrm{a}$ & 6,41 & $\mathrm{bc}$ & 8,59 & $\mathrm{bc}$ \\
\hline $\mathrm{k}_{3}=12.5$ ton $/ \mathrm{ha}$ & 4,94 & $\mathrm{~b}$ & 6,72 & $\mathrm{c}$ & 8,91 & $\mathrm{c}$ \\
\hline
\end{tabular}

Keterangan : Angka rata-rata yang diikuti huruf yang sama pada setiap kolom, tidak berbeda nyata berdasarkan Uji Jarak Berganda Duncan pada taraf nyata 5\%. 


\section{Diameter Batang (cm)}

Analisis hasil pengamatan diameter batang menunjukkan tidak terjadi interaksi amtara berbagai konsentrasi zat pengatur tumbuh hydrasil dan dosis pupuk kandang ayam terhadap diameter batang.

Tabel 3. Pengaruh Berbagai Konsentrasi Zat Pengatur Tumbuh Hydrasil dan Dosis Pupuk Kandang Ayam terhadap Diameter Batang (cm).

\begin{tabular}{|c|c|c|c|c|c|c|}
\hline \multirow{2}{*}{ Perlakuan } & \multicolumn{6}{|c|}{ Rata-rata diameter batang $(\mathrm{cm})$} \\
\hline & \multicolumn{2}{|c|}{$15 \mathrm{HST}$} & \multicolumn{2}{|c|}{$22 \mathrm{HST}$} & \multicolumn{2}{|r|}{$29 \mathrm{HST}$} \\
\hline \multicolumn{7}{|c|}{ Konsentrasi Zat Pengatur Tumbuh } \\
\hline $\mathrm{z}_{0}=0,0 \mathrm{ml} /$ liter air & 1,83 & A & 4,27 & a & 4,81 & $\mathrm{a}$ \\
\hline $\mathrm{z}_{1}=1.0 \mathrm{ml} /$ liter air & 1,89 & $\mathrm{Ab}$ & 4,51 & $\mathrm{~b}$ & 5,50 & $\mathrm{~b}$ \\
\hline $\mathrm{z}_{2}=1.5 \mathrm{ml} /$ liter air & 2,07 & $\mathrm{~B}$ & 5,01 & $\mathrm{c}$ & 5,95 & $\mathrm{c}$ \\
\hline $\mathrm{z}_{3}=2.0 \mathrm{ml} /$ liter air & 1,98 & $\mathrm{ab}$ & 4,83 & $\mathrm{c}$ & 5,94 & $\mathrm{c}$ \\
\hline \multicolumn{7}{|c|}{ Dosis Pupuk Kandang Ayam } \\
\hline $\mathrm{k}_{0}=0,0$ ton $/ \mathrm{ha}$ & 1,69 & A & 4,36 & A & 5,15 & $\mathrm{a}$ \\
\hline $\mathrm{k}_{1}=7.5$ ton $/ \mathrm{ha}$ & 1,88 & $\mathrm{ab}$ & 4,64 & $\mathrm{~B}$ & 5,51 & $\mathrm{~b}$ \\
\hline $\mathrm{k}_{2}=10,0$ ton $/ \mathrm{ha}$ & 2,03 & $\mathrm{bc}$ & 4,78 & $\mathrm{Bc}$ & 5,67 & $\mathrm{bc}$ \\
\hline $\mathrm{k}_{3}=12.5$ ton $/ \mathrm{ha}$ & 2,18 & $\mathrm{C}$ & 4,85 & $\mathrm{C}$ & 5,86 & $\mathrm{c}$ \\
\hline
\end{tabular}

Keterangan: Angka rata-rata yang diikuti huruf yang sama pada setiap kolom, tidak berbeda nyata berdasarkan Uji Jarak Berganda Duncan pada taraf nyata $5 \%$.

Meningkatnya diameter batang pada perlakuan konsentrasi 1,5 ml/liter air merupakan konsentrasi yang optimum, karena apabila konsentrasinya ditingkatkan akan menurunkan laju pertumbuhan tanaman, karena pada konsentrasi tersebut bahan aktif 2,4-D yang merupakan auksin sintetik berada dalam keadaan telah melewati titik jenuh, sehingga tidak lagi memberikan respon terhadap pertumbuhan bahkan dapat menghambat pertumbuhan tanaman, sedangkan pada konsentrasi yang lebih rendah kurang berperan terhadap pertumbuhan tanaman. Zat pengatur tumbuh merupakan senyawa yang terdiri dari senyawa aromatik dan bersifat asam yang berpengaruh terhadap proses fisiologi dan biokimia tanaman (Dwidjosoputro, 2005).

Penambahan pupuk kandang ayam dosis 12,5 ton/ha mampu meningkatkan diameter tanaman, meningkatnya diameter batang tersebut karena pupuk kandang ayam mengandung unsur hara makro yang dibutuhkan tanaman. Nitrogen yang terdapat dalam pupuk kandang ayam berperan menyusun enzim yang terdapat dalam sel, sehingga mempengaruhi produksi karbohidrat yang sangat berperan dalam pertumbuhan tanaman dan karbohidrat merupakan bahan yang sangat penting dalam pembelahan sel, perpanjangan sel, pembesaran sel dan pembentukkan jaringan untuk perkembangan batang (Prasetyo, 2005). 


\section{Bobot Segar Tanaman (gr)}

Analisis hasil pengamatan bobot segar tanaman menunjukkan terjadi interaksi antara berbagai konsentrasi zat pengatur tumbuh hydrasil dan dosis pupuk kandang ayam terhadap bobot segar tanaman.

Tabel 4. Pengaruh Berbagai Konsentrasi Zat Pengatur Tumbuh Hydrasil dan Dosis Pupuk Kandang Ayam terhadap Bobot Segar Tanaman (gr).

\begin{tabular}{|c|c|c|c|c|c|c|c|c|}
\hline \multirow{2}{*}{ Perlakuan } & \multicolumn{8}{|c|}{ Rata-rata bobot segar per tanaman (gr) } \\
\hline & \multicolumn{8}{|c|}{ Dosis Pupuk Kandang Ayam } \\
\hline \multirow{2}{*}{$\begin{array}{l}\text { Konsentrasi Zat Pengatur } \\
\text { Tumbuh }\end{array}$} & \multirow{2}{*}{\multicolumn{2}{|c|}{$\begin{array}{c}\mathrm{k}_{0}= \\
, 0 \text { ton } / \mathrm{ha}\end{array}$}} & \multirow{2}{*}{\multicolumn{2}{|c|}{$\begin{array}{c}\mathrm{k}_{1}= \\
7.5 \text { ton/ha }\end{array}$}} & \multirow{2}{*}{\multicolumn{2}{|c|}{$\begin{array}{c}\mathrm{k}_{2}= \\
10,0 \text { ton/ha }\end{array}$}} & \multirow[t]{2}{*}{$\mathrm{k}_{3}=$} & \multirow[t]{2}{*}{12.5 ton/ha } \\
\hline & & & & & & & & \\
\hline \multirow[t]{2}{*}{$\mathrm{z}_{0}=0,0 \mathrm{ml} /$ liter air } & 103,00 & $\mathrm{a}$ & 107,40 & $\mathrm{a}$ & 136,90 & $\mathrm{a}$ & 149,20 & $\mathrm{a}$ \\
\hline & A & & A & & B & & $\mathrm{C}$ & \\
\hline \multirow{2}{*}{$\mathrm{z}_{1}=1.0 \mathrm{ml} /$ liter air } & 138,00 & $\mathrm{~b}$ & 146,55 & $\mathrm{~b}$ & 163,35 & $\mathrm{~b}$ & 167,35 & $\mathrm{~b}$ \\
\hline & A & & A & & B & & B & \\
\hline \multirow[t]{2}{*}{$\mathrm{z}_{2}=1.5 \mathrm{ml} /$ liter air } & 147,65 & bc & 165,05 & $\mathrm{c}$ & 173,95 & $\mathrm{~b}$ & 193,15 & $\mathrm{c}$ \\
\hline & A & & $\mathrm{B}$ & & $\mathrm{B}$ & & $\mathrm{C}$ & \\
\hline \multirow[t]{2}{*}{$\mathrm{z}_{3}=2.0 \mathrm{ml} /$ liter air } & 150,45 & $\mathrm{c}$ & 165,45 & $\mathrm{c}$ & 170,95 & $\mathrm{~b}$ & 188,85 & $\mathrm{c}$ \\
\hline & A & & $\mathrm{B}$ & & $\mathrm{B}$ & & B & \\
\hline
\end{tabular}

Keterangan : Angka rata-rata yang diikuti huruf kecil yang sama pada arah vertikal dan huruf besar yang sama pada arah horizontal, tidak berbeda nyata berdasarkan Uji Jarak Berganda Duncan pada taraf nyata 5\%

Interaksi antara konsentrasi zat pengatur tumbuh dan dosis pupuk kandang ayam berdasarkan Tabel 4. Menurut Heddy (1996) bahwa ZPT merupakan senyawa yang diberikan pada tanaman sebagai suplemen tambahan untuk meningkatkan proses pembelahan sel agar lebih aktif lagi. ZPT yang diaplikasikan dalam penelitian ini berbahan aktif 2,4-D yang merupakan salah satu zat pengatur tumbuh golongan auksin sintetik dengan konsentrasi 1,5 ml mampu merangsang pembelahan dan perbesaran sel.

sedangkan pupuk kandang ayam dengan dosis 12,5 ton/ha dapat memperbaiki sifat fisik, kimia dan biologi tanah, menurut Harjdowigeno (2010) pemberian pupuk organik berfungsi menambah kandungan hara dalam tanah, memperbaiki struktur tanah, meningkatkan kemampuan tanah menahan air dan meningkatkan kegiatan biologi tanah. Dengan diaplikasikannya dua bahan tersebut akan meningkatkan bobot segar tanaman.

Terjadinya interaksi antara konsentrasi ZPT dengan pupuk kandang ayam disebabkan karena pemberian ZPT dalam konsentrasi yang tepat yang disertai pemberian pupuk kandang ayam akan meningkatkan pertumbuhan dan perkembangan tanaman

\section{Hasil Segar Tanaman per Plot (kg)}

Analisis hasil pengamatan hasil segar tanaman per plot menunjukkan terjadi interaksi antara berbagai konsentrasi zat pengatur tumbuh hydrasil dan dosis pupuk kandang ayam terhadap hasil segar tanaman per plot. 
Tabel 5. Pengaruh Berbagai Konsentrasi Zat Pengatur Tumbuh Hydrasil dan Dosis Pupuk Kandang Ayam terhadap Hasil Segar Tanaman per Plot (kg).

\begin{tabular}{|c|c|c|c|c|c|c|c|}
\hline \multirow{2}{*}{ Perlakuan } & \multicolumn{7}{|c|}{ Rata-rata hasil segar tanaman per plot (kg) } \\
\hline & \multicolumn{7}{|c|}{ Dosis Pupuk Kandang Ayam } \\
\hline $\begin{array}{l}\text { Konsentrasi Zat Pengatur } \\
\text { Tumbuh }\end{array}$ & $\begin{array}{r}\mathrm{k}_{0}=0 \\
\text { ton } / \mathrm{ha}\end{array}$ & & $\begin{array}{r}\mathrm{k}_{1}=7 \\
\text { ton/ha }\end{array}$ & & $\begin{array}{c}\mathrm{k}_{2}= \\
10,0 \text { ton/ha }\end{array}$ & $\mathrm{k}_{3}=$ & 12.5 ton/ha \\
\hline $\mathrm{z}_{0}=0,0 \mathrm{ml} /$ liter air & $\begin{array}{r}3,34 \\
\mathrm{~A}\end{array}$ & $\mathrm{a}$ & $\begin{array}{r}3,473 \\
\mathrm{~A}\end{array}$ & $\mathrm{a}$ & $\begin{array}{rl}4,49 & \mathrm{a} \\
\mathrm{B} & \end{array}$ & $\begin{array}{r}4,58 \\
\mathrm{C}\end{array}$ & $\mathrm{a}$ \\
\hline $\mathrm{z}_{1}=1.0 \mathrm{ml} /$ liter air & $\begin{array}{r}3,59 \\
\mathrm{~A}\end{array}$ & $\mathrm{a}$ & $\begin{array}{r}4,45 \\
\mathrm{~B}\end{array}$ & $\mathrm{~b}$ & $\begin{array}{r}4,60 \text { ab } \\
\mathrm{BC}\end{array}$ & $\begin{array}{r}4,91 \\
\mathrm{C}\end{array}$ & $\mathrm{ab}$ \\
\hline $\mathrm{z}_{2}=1.5 \mathrm{ml} /$ liter air & $\begin{array}{r}4,284 \\
\mathrm{~A}\end{array}$ & $\mathrm{~b}$ & $\begin{array}{r}4,68 \\
\mathrm{AB}\end{array}$ & bc & $\begin{array}{rl}5,01 & \mathrm{c} \\
\mathrm{BC} & \end{array}$ & $\begin{array}{r}5,37 \\
\mathrm{C}\end{array}$ & $\mathrm{c}$ \\
\hline $\mathrm{z}_{3}=2.0 \mathrm{ml} /$ liter air & $\begin{array}{r}4,418 \\
\mathrm{~A}\end{array}$ & $\mathrm{~b}$ & $\begin{array}{r}4,88 \\
\mathrm{AB}\end{array}$ & $\mathrm{c}$ & $\begin{aligned} 4,92 & \text { bc } \\
\text { BC } & \end{aligned}$ & $\begin{array}{r}5,08 \\
\mathrm{C}\end{array}$ & bc \\
\hline
\end{tabular}

Keterangan : Angka rata-rata yang diikuti huruf kecil yang sama pada arah vertikal dan huruf besar yang sama pada arah horizontal, tidak berbeda nyata berdasarkan Uji Jarak Berganda Duncan pada taraf nyata 5\%

Terjadinya interaksi antara konsentrasi ZPT dan dosis pupuk kandang ayam, karena antara zat pengatur tumbuh sengan dosis pupuk kandang ayam terdapat hubungan saling mempengaruhi dalam meningkatkan hasil tanaman. Pemberian zat pengatur tumbuh dengan konsentrasi 1,5 $\mathrm{ml} /$ liter air akan memberikan pertambahan hasil segar tanaman bila diimbangi dengan pemberian pupuk kandang ayam dengan dosis yang tepat.

Penggunaan zat pengatur tumbuh secara tepat dapat mempengaruhi jaringan berbagai organ maupun sistem organ tanaman, diantaranya merangsang pertumbuhan akar dan meningkatkan proses fotosintesis tanaman, maka dengan berkembangnya sistem perakaran sebagai akibat dari pemberian zat pengatur tumbuh, maka penyerapan unsur hara dalam tanah yang berasal dari suplai pupuk kandang ayam lebih efektif, sehingga memacu pertumbuhan tanaman lebih baik yang ditunjukkkan dengan meningkatnya hasil tanaman per plot (Marliah dkk. 2010).

\section{Kesimpulan}

1. Terjadi interaksi antara konsentrasi ZPT hydrasil dan dosis pupuk kandang ayam terhadap bobot segar tanaman dan hasil segar tanaman per plot.

2. Kombinasi perlakuan konsentrasi ZPT hydrasil 1,5 ml/liter air dengan dosis pupuk kandang ayam 12,5 ton/ha berpengaruh terbaik terhadap pertumbuhan dan hasil tanaman pakchoy.

\section{Daftar Pustaka}

Badan Pusat Statistik, 2018. Produksi tanaman pakchoy di Indonesia. (On-line) http://bps.go.id. Diakses tanggal 7 Agustus 2021. 
Darnell, J., H. Lodish and H. Baltimore. 1986. Molecular Cell Biology. Scientific American Books, Inc. New York.

Dwidjoseputro. 2005. Dasar-Dasar Mikrobiologi.Yogjakarta: Djambatan

Gardner FP, Pearce RB, Mitchell RL. 1991. Fisiologi Tanaman Budidaya. Penerjemah Herawati Susilo. UI Press, Jakarta.

Hardjowigeno, S. 2010. Ilmu Tanah. CV Akademika Pressindo. Jakarta.

Heddy, S. 1996. Hormon Tumbuhan. Raja Grafindo Persada. Jakarta.

Marliah, A., Jumini, Jamilah, 2010. Pengaruh Jarak Tanam Antar Barisan pada Sistem Tumpangsari Beberapa Varietas Jagung Manis dengan Kacang Merah terhadap Pertumbuhan dan Hasil. J. Agrista Vol. 14.

Novizan. 2005. Petunjuk Pemupukan yang Efektif. Agromedia Pustaka, Jakarta.

Purwitasari, A.T., M.A. Alamsjah, dan B.S. Rahardja. 2012. Pengaruh Konsentrasi Zat Pengatur Tumbuh (Asam-2,4-Diklorofenoksiasetat) terhadap Pertumbuhan Nannochloropsis oculata. Journal of Marine and Coastal Science, Vol. 1(2), 61-70.

Prasetyo, B. H. 2005. Mineral Tanah. Bogor: Balai Peneliti Tanah.

Sudiarto dan Gusmaini. 2004. Pemanfaatan Bahan Organik In Situ untuk Efisiensi Budidaya Jahe yang Berkelanjutan. Jurnal Litbang Pertanian, Vol. 23(2): 37-45.

Sutejo, M.M. 2005. Pupuk dan Pemupukan. Rineka Cipta, Jakarta.

Warsa, T. dan C.S. Akhyar. 1982. Teknik Perancangan dan Percobaan. Fakultas Pertanian Universitas Padjadjaran. Bandung 